\title{
HISTOLOGICAL AND HISTOCHEMICAL CHANGES OF THE SKEILTAL MUSCLE IN HUMAN CHRONIC CHAGAS' DISEASE
}

\author{
ANALIA TARATUTO \\ TERESA FUMO
}

M. A. PAGANO

OLGA P. BANZ
R. E. P. 8ICA

In a recent electrophysiological investigation Pagano et al.4 demonstrated the presence of mild denervation in the skeletal muscle of patients with chronic Chagas' disease. Later on, the Ramos Mejía Hospital's group confirmed the findings of Pagano et al.4 and pointed out the spinal alpha motoneurone soma as the site of the lesion within the motor unit (m.u.)s.

The aim of the present study has been to obtain information concerning the eventual histological changes of the skeletal muscle of patients with chronic Chagas' disease.

\section{MATERIAL AND METHODS}

Open biopsies were carried out under local anaesthesia on the gastrocnemius medial head muscle in 7 subjects, 5 males and 2 females, aged between 25 and 44 years. A thorough history was obtained from each patient and a complete clinical and laboratory examination was also performed; on these bases the selected subjects were Judged to be healthy, being the only abnormality detected the presence of 2 out of 3 positive serum tests for Chagas disease. None of them had been previously treated with specific drugs.

Coincidental causes of muscle denervation were avoided by rejecting patients over the age of 60 years 1,6 and those with a history of toxic or metabolic disorders known to be associated with muscle denervation. Also were eliminated those patients with personal or family history of muscle disease.

Fresh muscle specimens were frozen in isopentane cooled to $-150 \mathrm{Co}$ in liquid nitrogen. Cryostat sections were cut at thickness of 2 to 10 um and were stained or reacted with the following techniques: hemaetoxilin-eosin, periodic acid Schiff, modifled Gomori trichrome, reduced nicotinamide adenine dinucleotile dehidrogenase (NADH), miofibrillar adenosine triphosphatase (ATPase) at pH 9.4 and 4.6. alkaline phosphatase and non-specific esterase.

\section{RPSULTS}

The most common finding was the presence of clusters of uniform type of muscle fibres, either type I or type II, in 5 of the 7 studied patients. Both types of clusters, placed side by side, could often be found in the same specimen (Figure 1 . Table 1).

\footnotetext{
Section of Clinical Hectroneurophysiology, Hospital Ramos Mefia, Buenos Aires. Argentina.
} 


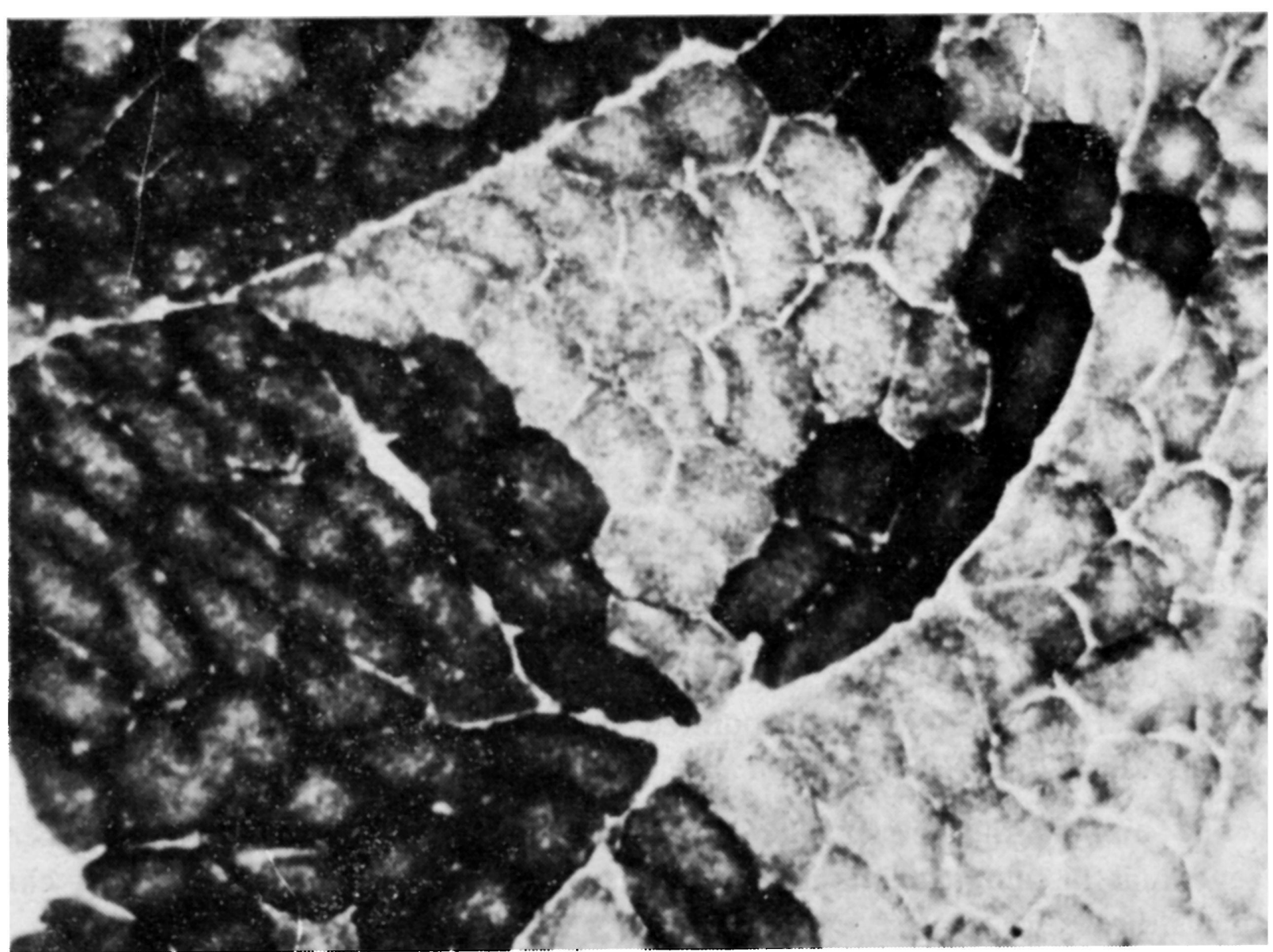

Fig. 1 - Fibre type grouping (NADH, 168x).

\begin{tabular}{|c|c|c|c|c|c|}
\hline \multirow[t]{2}{*}{ Patients } & \multirow[t]{2}{*}{ Sex } & \multirow{2}{*}{$\begin{array}{c}\text { Age } \\
\text { (years) }\end{array}$} & \multirow{2}{*}{$\begin{array}{c}\text { Small } \\
\text { angula! } \\
\text { fibres }\end{array}$} & \multicolumn{2}{|c|}{ Fibre type grouping } \\
\hline & & & & small & large \\
\hline v.Ch. & $\mathbf{M}$ & 32 & + & $+($ II) & \\
\hline M.A. & $\mathbf{M}$ & 93 & - & $+(\mathrm{II})$ & \\
\hline H.A. & $\mathbf{F}$ & 31 & - & - & \\
\hline F.S. & $\mathbf{M}$ & 25 & - & $+(\mathrm{II})$ & \\
\hline O.R. & $\mathbf{M}$ & 44 & + & - & $+(\mathrm{I}, \mathrm{II})$ \\
\hline C.R. & $\mathbf{F}$ & 28 & - & $+(I)$ & \\
\hline A.R. & $\mathbf{M}$ & 38 & - & - & \\
\hline
\end{tabular}

Table 1 - Histological and histochemical findings. In the 5 th row numbers in brackets signal muscle fibre type grouping.

The clusters were composed of about 16 to 30 fibres, being small in 4 patients while in the remaining one much larger clusters could be seen (Table 1).

In patients V. Ch and O. R. small angular fibres, which stained or reacted strongly with non-specific sterase and NADH techniques, were also observed (Figure 2, Table 1).

Neither degenerative muscle changes nor architectural abnormalities were seen. 


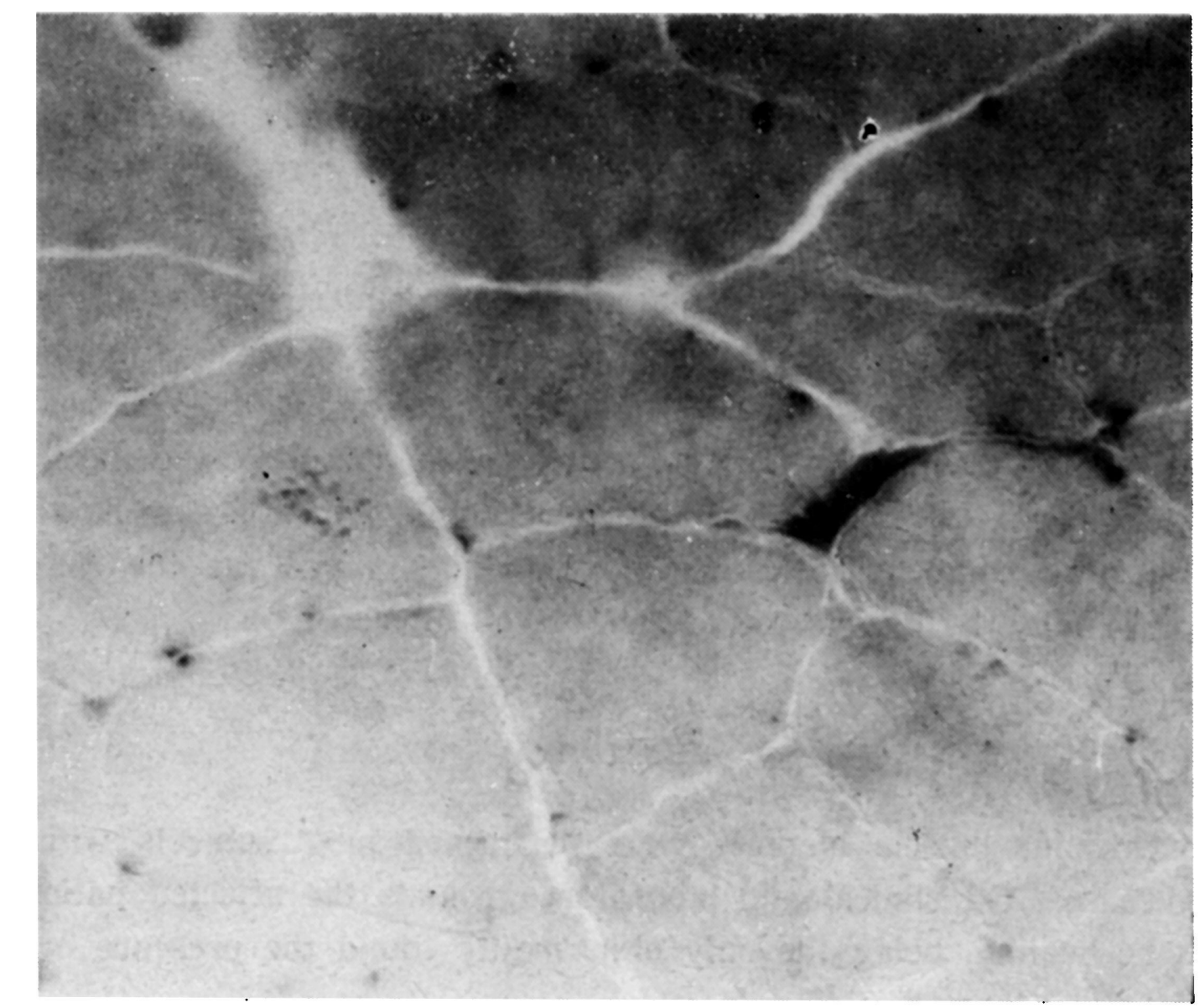

Fig. 2 - Small angular denervated fibres (non-specific sterase, sł8x).

\section{DISCUSSION}

The present study has shown the presence of scattered at random denervated atrophic muscle fibres and fibre type grouping, both features were found twice in the same sample, while in the other three patients only grouped fibres of either type I or type II were seen.

These observations strongly suggest denervation associated with reinervation', nevertheless these findings do not imply an associated clinical symptomatology, for fibre type grouping can be the only finding in clinically uninvolved muscles when there has been an adequate compensation in a chronic denervation.

It should be mentioned that in a previous study Laguens et al. ${ }^{3}$ found in the human biceps of EVI-positive chagasic patients non specific muscle histological changes, namely isolated hyalinazed fibres, increased number of central nuclei in some fibres and occasionally sprouting buds containing numerous nuclei. They did not find alterations of succinate dehydrogenase and ATPase activities and no clear distinction between fibre types could be done by employing the phosphorilase technique.

The changes observed in our histological study, which resulted from denervation, do not point out the site of lesion within the neurogenic component of the m.u., for either the axon or the motoneurone soma may bring about the same histological picture. However, the electrophysiological evidences presented by Sanz et al.5 hint that the motoneurone soma may be the site of 
lesion. Their ideas agree with our findings in two aspects: first the observed muscle changes may be the result of motoneurone soma involvement and second, the described anatomical features can be found in partially denervated subjects who have recovered from a denervatory disease and, eventually, have not anv clinical symptomatology.

In conclusion, the present investigation has confirmed electrophysiological studies in which an involvement of the m.u. was reported in patients with chronic Chagas' disease ${ }^{4,5}$. Because the approach applied here has been a morphological rather than a physiological one, it has had the advantage of showing anatomical evidences of muscle denervation which are compatible with an old and well compensated denervatory process which, at the time of the investigation, may be below the clinical level of detection.

\section{SUMMARY}

Gastrocnemius muscle biopsies were performed in 7 subjects with chronic Chagas' disease. On clinical and laboratory grounds the selected patients were judged to be healthy, being the only abnormality found the presence of positive serum tests for Chagas' disease.

Fibre type grouping of either type I or type II was observed in 5 of the 7 patients. Furthermore, in 2 of the 5 patients showing muscle fibre groupings, angular fibres reacting with $\mathrm{NADH}$ and non-specific sterase were also found. These observations strongly suggest denervation associated with reinervation. This picture often can be observed in the skeletal muscle of patients with well compensated denervatory conditions who do not show clinical evidences of denervation.

\section{RERSUMFN}

Cambios histológicos e histoquímicos del músculo esquelético en la enfermedad de Chagas crónica.

En 7 pacientes afectados por enfermedad de Chagas crónica se procedió al estudio biópsico del músculo gastrocnemio. Los pacientes seleccionados mostraran como única anormalidad la presencia de tests positivos en suero para la enfermedad de Chagas. Agrupamiento de fibras musculares de tipo I y II fué observado en 5 de aquellos; en 2 de estos últimos 5 se encontró, además, fibras anguladas que se teñian intensamente con NADH y esterase no especifica. Las observaciones hechas sugirieron la presencia de denervación seguida por reinervación, cuadro que puede ser observado con asiduidad en el músculo esquelético de pacientes con afecciones denervatorias bien compensadas y en los que no existen evidencias clínicas de ese compromiso. 


\section{REFHRENCES}

1. CAMPBELL, M. J.; McCOMAS, A. J. \& PETITO, F. - Physiological changes in ageing muscles. J. Neurol. Neurosurg. Psychiat. (London) 36:174, 1973.

2. RARPATI, G. \& FNGH, W. K. - Type grouping in skeletal muscle after experimental reinervation. Neurology (Minneapolis) 18:447, 1968.

3. LAGUENS, R. P.; COSSIO, P. M.; DIFZ, C.; SHGAL, A.; VAzQUHZ, C.; KRHUTZTR, F.; KHOURY, E. \& ARANA. R. M - Inmunopathologic and morphologic studies of skeletal muscle in Chagas' disease. Am J. Pathology (Chicago) 80:153. 1975.

4. pagano, M. A.; aristimuno, G. G.; Basso. susana; colombi, A. \& sica. R. F. P. - Electromyographical findings in chronic Chagas' disease. Arq. NcuruPsiquiat. (São Paulo) 36:316, 1978.

5. SANZ, OLGA, P.; RATUSNU, A. F.: ARISTIMUNO. G. G.; O'NEILI, E. M. \& SICA, R. H. P. - An electrophysiological investigation of skeletal muscle in human chronic Chagas' disease. Arq. Neuro-Pgiquiat. (SĔo Paulo) 36:319, 1978.

6. SICA, R. H.P.; SANZ, OLGA P. \& COLOMBI, A. - The effect of ageing uppon the human soleus muscle. Medicina (Buenos Aires) $36: 443,1976$.

Reprint requeat: Dr. R. E. P. BICA - Beocion de Eleotroneurofioiología Clinica.Hospital Ramos Mefia - Urquiza 609 - Buenos Aires - Argentina. 